\title{
From the 'Real' Author to the 'Real' Reader: Manipulation in Translation
}

\section{Asl1 KALEM BAKKAL*}

The aim of this article is to examine an edition of Mustafa Kemal Atatürk's Nutuk (The great speech) from the perspective of translation studies. The research subject is Mustafa Kemal Atatürk'ün Anlatımıyla Çocuklar için Nutuk (The great speech for children with Mustafa Kemal Atatürk's narration), intralingually translated by Hakan Atalay (2018). This edition has been selected for examination among many others, because on the copyright page of the edition Atalay has been presented as the 'author' of the book and children as its target reader on the cover. In the present article, both claims will be questioned from the perspective of translation studies with an interdisciplinary approach where the narratological framework will be used in the analysis of the book which I consider not only as an example of intralingual translation but also a translation between genres. For this purpose, the present article will take O'Sullivan's (2003) article as its reference point in which the scholar elaborates the narrative diagram put forward by Chatman (1978) by adding a translational dimension to it. Based on the analysis, the article will conclude with some questions about manipulation in translation with the hope that they will lead the way to new discussions in translation studies.

Keywords: Nutuk; intralingual translation; narration; manipulation; author

\section{Introduction}

Mustafa Kemal Atatürk's famous speech Nutuk ${ }^{1}$ delivered by him from 15 to 20 October 1927 at the second congress of the Republican People's Party was first published in Arabic letters in 1927, and later in Latin letters, in 1934. Since then, it has been published many times and it has always drawn great interest both in Turkey and abroad thanks to its historical, social, and cultural nature. On the other hand, it would not be wrong to say that we may have not witnessed a time as prolific as today in terms of Nutuk publications ${ }^{2}$. It is possible to find

\footnotetext{
* Part-time instructor at İzmir University of Economics; PhDc at Istanbul 29 May1s University. E-mail: aslibakkal71@gmail.com; ORCID ID: https://orcid.org/0000-0002-3952-1394.

(Received 18 February 2019; accepted 20 June 2019).

${ }^{1}$ Throughout the article, I will refer to The Great Speech with its original name in Turkish, Nutuk, except for the translated parts.

${ }^{2}$ Throughout the paper, different editions of Nutuk will be mentioned. As Mustafa Kemal Atatürk is the author of all of them, to avoid confusion in terms of reference, both in-text quotations and bibliographical items at the end of the paper will be given with translators' names whenever available. However, since the books used in this study name the intralingual process and the people carrying it out differently, they will all be referred to as 'editors' in references in line with the Chicago Manual of Style despite the fact that the article qualifies them as 'translators.'
} 
different editions aiming at specific target reader groups, mainly defined by age: Nutuk 'for the youth,' 'for the elementary school students,' and 'for children,' to name a few.

\section{Historical Background}

Derived from and responding to the need of making older texts intelligible to younger generations, intralingual translation has been a widely used tool in Turkey's modernization efforts, especially after the language reform (Berk 2013, 257) and Nutuk has occupied a distinctive place also in this respect. The preface for the 1963 edition of Nutuk reads: ${ }^{3}$

It has been more than thirty-five years since Atatürk delivered The Great Discourse. ${ }^{4}$ In the meantime, our language has developed and changed to a large extent. In fact, today's new generation cannot properly understand The Great Discourse which is the most important source of light and power for them because many words in The Great Discourse are no longer in use and many words have lost their old meaning. ... Noticing the situation, Turkish Language Association has decided to have The Great Discourse by the great leader Atatürk be translated for today's young generations. ${ }^{5}$ (quoted in Velidedeoğlu 1998, 28)

\section{The Genre of Nutuk}

Although different definitions underline different aspects of Nutuk, there is a consensus in terms of its genre, emphasizing its importance as a historical document. Demirel $(2018,11)$ states, "The Great Speech is essentially a military, political and diplomatic history of the National Struggle period, given from the perspective of Mustafa Kemal Pasha." ${ }^{6}$ On the back cover of Velidedeoğlu's (1998) Söylev translation, it reads that "The Great Discourse is an autobiography, in the period of 1919-1927, written by Atatürk himself. The Great Discourse is in a way a top-end, first-hand diary of the stages of the National War of Independence and the Turkish Revolution."7

\footnotetext{
${ }^{3}$ All translations are mine unless otherwise stated.

${ }^{4}$ The Great Speech and The Great Discourse refer to Nutuk and Söylev, respectively, to denote the distinction between the two terms, the latter being the newer word for the former, with the same meaning.

${ }^{5}$ Atatürk'ün Söylev'i verişinden beri otuz beş yıldan çok bir zaman geçti. Bu zaman içinde dilimiz çok gelişti, çok değişti. Öyle ki, artık bugünün genç kuşakları, kendileri için en önemli bir 1şık ve güç kaynağı olan bu büyük Söylev’i gereği gibi anlayamıyorlar. Çünkü Söylev’deki birçok sözcükler bugün kullanılmaktan düştü. Birçok sözcükler de eski anlamlarını yitirdiler. . . . Bu durumu iyi kavrayan Türk Dil Kurumu, Büyük Ata’nın Söylev’ini genç kuşaklar için bugünün Türkçesine çevirtmeyi kararlaştırdı.

${ }^{6}$ Nutuk esas olarak, Mustafa Kemal Paşa'nın gözünden, Milli Mücadele döneminin askeri, siyasi ve diplomatik bir tarihidir.

${ }^{7}$ Söylev, 1919-1927 döneminde, Atatürk'ün kendi kaleminden çıkmış bir öz yaşam öyküsüdür. Söylev, Ulusal Kurtuluş Savaşı'nın ve Türk devrimi aşamalarının üst düzeyde, ilk elden tutulmuş bir güncesi niteliğindedir.
} 


\section{Intralingual Translation}

Although achieving a simpler, easily understandable language is the common aim of many intralingually translated texts, the names attributed to intralingual translation itself, the "interpretation of verbal signs by means of other signs of the same language" as Jakobson ([1959] 2000, 114) defines it, differ to a great extent. As pointed out by Berk $(2013,258)$, "these new versions of older literary texts are not presented and accepted as intralingual translations, but as 'simplified' (sadeleştirilmiş) or 'Turkified' (Türkçeleştirilmiş) editions, 'arranged' (düzenlenmiş), and 'prepared for publishing' (yayına hazırlanmıs) among others." Nutuk presents a wide repertoire in this regard. Velidedeoğlu $(1998,28)$ defines the 1963 edition as a 'Turkified' (Türkçeleştirilmiş) text while Berktay (2016), in the preface, talks about a 'simplification' (sadeleştirme) "without damaging the essence of the text at all." Düzenleyen (Arranged by; Kalecikli 2017), Yayına Hazırlayan (Edited by; Korhan 2018) and Günümüz Türkçesiyle Özetleyerek Aktaran (Summarized and transferred in today's Turkish by; Berktay 2016), Günümüz Türkçesine Uyarlayan (Adapted into today’s Turkish by; Doğan 2017) are among other naming options seen on covers, inner covers and copyright pages.

In these editions aiming at children, metatextual elements play an important role; pictures, photographs, drawings are used abundantly. Layout, use of fonts (mostly sans serif), font size also contribute to the simplicity of message transfer. This use of metalinguistic elements is even emphasized with explanations on the covers: Gençler Iç̧in Fotoğraflarla Nutuk (The great speech with photographs for the youth; Berktay 2016), Renkli Koleksiyon Serisi (Coloured collection series; Bilici 2017), Resimli Özel Baskı (Special edition with pictures; Balpinar 2019).

Although none of the editions gone over by the author of the present study that have children as their target reader group define the process as 'translation,' and although not expressed anywhere in these editions, it would not be wrong to assume that all of them take Atatürk's Nutuk or some intralingual translations of it as their departure point, namely as their source text, an easily identifiable fact revealed even just by their title.

\section{O'Sullivan's Expanded Diagram Including Translation}

In order to better grasp O'Sullivan's point of view, it will be necessary to look at Chatman's model first as it forms the basis for the one proposed by O'Sullivan. 
In Story and Discourse, Chatman's $(1978,151)$ narrative communication model is given in his well-known diagram as in figure 1:

Fig. 1. Chatman's narrative text diagram

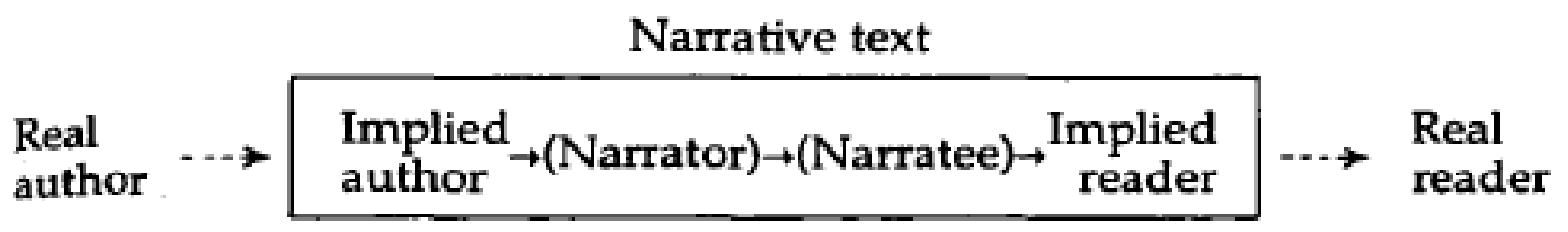

The diagram consists of six parties forming three pairs: the real author-the real reader, the implied author-the implied reader, and the narrator-the narratee.

O'Sullivan (2003) defines the narrative text as "the message transmitted from the real author to the real reader," where the real author is "the one who pysically wrote the text of the book," and the real reader is "the one who holds it in her/his hands and reads it (or has it read to her/him)" (199; original emphasis).

The implied author, as an indispensable 'agency' of every fiction, acts in a sense as the author's representative in the book. Chatman $(1990,75)$ argues that "the real author retires from the text as soon as the book is printed and sold," and what is left in the text is the implied author, namely a "silent instructor" (O'Sullivan 2003, 199) who is "within the narrative fiction itself which guides any reading of it" (Chatman 1990, 74). Specific to children's literature, O'Sullivan $(2003,199)$ notes that the implied author is the "agency" that "bridge[s] the distance between 'adult' [generator of the text] and 'child' [reader of it]." The implied reader, on the other hand, is created by the "all-informing" implied author and "inscribed in the text" as the audience envisaged by the narrative.

The narrator is the voice telling the story, therefore the only audible one in the narration, as opposed to the silent implied author. The narrator addresses the narratee; the latter can remain silent throughout the story or can have its own voice as a character in the narrative (O'Sullivan (2003, 199).

In the same article, O'Sullivan also points out that Chatman's model can be applied to an original text but not to a translation since in the latter "the message transmitted by the real author in the source language is read by the real reader in the target language" (200). 
Accordingly, the scholar expands Chatman's diagram by adding translational elements to it and comes up with the one shown in figure 2:

Fig. 2. O'Sullivan's diagram of translation in narrative communication

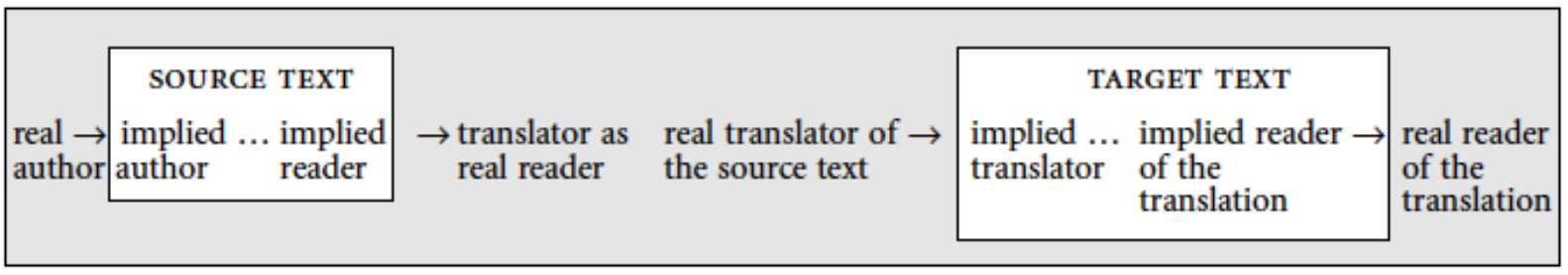

In this diagram, translator is first positioned as the real reader of the source text. "As someone familiar with the source language as well as the conventions and norms of that culture, $\mathrm{s} / \mathrm{he}$ is in a position to slip into the role of the implied reader of the source text" (O'Sullivan 2003, 201). It is after this stage that O'Sullivan's diagram differs from Chatman's as translation comes to the fore and the translator as the real reader of the source text turns into the real translator of it. O'Sullivan bases the role played by the translator on the parallelism between the two texts. While the target text is parallel to the source text, the translator as the creator of the translation is parallel to the real author of the source text (201).

According to O'Sullivan, the implied reader of the translation will never be the same as the implied reader of the source text as their generators are different. Whereas in the source text the implied author creates its own implied reader, the implied reader of the target text is created by a similar agency, "the implied translator" (201; original emphasis).

Although all the discussions and definitions by O'Sullivan are based mainly on interlingual translations, the same framework can be applied to intralingual translation equally well as the book examined in the present study will prove.

\section{Atatürk'ün Anlatımıyla Nutuk (The great speech with the narration of Atatürk) ${ }^{8}$}

The book in question has the same title on its cover as many other editions aimed at children: Çocuklar için Nutuk (The great speech for children). It depicts the photographs of

\footnotetext{
${ }^{8}$ This title is not given on the cover, but on the inner cover as Mustafa Kemal Atatürk'ün Anlatımıyla Çocuklar için Nutuk. As this 'subtitle' specifies the book and its strategy very clearly, I have chosen to refer to the book with this title throughout the paper.
} 
Mustafa Kemal Atatürk, just like many others. Famous quotes of Atatürk are also used on some covers and the cover of Atatürk'ün Anlatimiyla Nutuk is no exception in this regard either.

As to the name of the author, some of the books in this category gone over within the scope of the present article use the full name, Mustafa Kemal Atatürk, while others prefer using his signature and one of them uses the word 'yazar' (author) next to his name. Only Atatürk' 'ün Anlatimiyla Nutuk uses the word "author" but not for Atatürk and not on the cover. On the cover, Mustafa Kemal Atatürk's signature is given next to the title Nutuk, but on the copyright page the "author" of the book is given as Hakan Atalay, the person who carried out the intralingual translation.

The narrative framework used as the translation strategy may have led to such a decision.

\section{Atatürk'ün Anlatımıyla Nutuk in the Narrative Framework}

Going back to Chatman's definitions with an attempt to fit the original Nutuk into his diagram as if it were a narration, we would certainly write the name of Mustafa Kemal Atatürk next to 'the real author.' 'The implied author' would probably be a man from within the country telling his people - and indirectly the whole world - how he achieved his goal together with his people, as the definition "the idea of the author carried away by the real reader after reading the book" (O'Sullivan 2003, 199) suggests. While 'the implied reader' would be the whole Turkish nation wishing to fully understand what took to achieve the liberation and the revolutions, due to the linguistic characteristics and intensiveness of the content, "the real reader' would be mostly adults and the Turkish youth whom the very last section directly adresses.

If we refer to O'Sullivan's expanded diagram based on Chatman's, on the other hand, Atalay would be first 'the real reader' of the source text, then he would turn into 'the real translator' of it. Additionally, as the implied and real reader groups of the source text differ from the implied and real readers of the target text that is said to be addressing mainly to children, the translator in this specific case would be expected to act also as a bridge between adult and child, as O'Sullivan claims.

Then, as the diagram suggests, we would expect a 'narrator' and a 'narratee.' Atalay, taking the position of the real translator, "transmits the source text via the intratextual agency 
of the implied translator" and via his implied translator, he generates his "narrator," "narratee," and "implied reader" (O'Sullivan 2003, 202; original emphasis). Doing this, he creates a new "relationship" between the "translated text' and a new group of readers" (Schiavi 1996, 7; in Atalay's case, 'groups' of readers as it will be illustrated in the following sections).

To find out the way the translator has followed to build up such a relation in this particular case, Atatürk'ün Anlatımıyla Nutuk has been analyzed in the framework of section headings, additions, omissions and tone.

\subsection{Section Headings}

Atalay (2018) has opted for a totally new sectioning in the book and come up with new headings for these sections. A consistency in the use of some elements in creating these headings is worth noticing.

7.1.1 Animal names. The abundant use of animal names that we often see in fables brings to mind the effort to make a historical text look and sound similar to a narration which children are usually familiar with: Tilkinin Kürkü (The fur of the fox; 73), Köstebek ve Labirent (The mole and the labyrinth; 76), Kuyuya Düssen Kurbağa (The frog that fell in the well; 81), Akbabalar ve Ateş Böcekleri (The vultures and the fireflies; 91), Yllanlar ve Çlyanlar (The snakes and the centipedes; 96), Telgraf Teline Konan Uğursuz Karga (The sinister crow that settles on telegraph wire; 107), Güvercinler Arasindaki Kedi (The cat among the pigesons; 109), Aslan Olmaya Kalkan Eşek (The donkey that attempts to become a lion; 134).

7.1.2 Proverbs. Balı̆g Yüzme Öğretilmez (One cannot teach a fish how to swim; 50) ${ }^{9}$, Köpekler İstedi Diye Atlar Ölmez (Horses do not die just because dogs asked for it; 42) ${ }^{10}$, Ayının İnine Girmeyeceksin (One should not enter into the bear's cave; 42), Örümcek Ağ Yaptıkça Yürür (The spider advances as it spins; 198) are some of the proverbs used as section headings (note that as the ones here illustrate also some of the proverbs contain animal names). Remembering that all narrations, aside from entertaining, are also expected to have an educative aspect, the use of proverbs here can be thought of not only as a narrative element but also as an educative means which may lead an average child to wonder the meaning and look for an explanation.

\footnotetext{
${ }^{9}$ A Chechenian proverb.

${ }^{10}$ A Roman proverb.
} 
7.1.3 Use of parts or titles from other works (verses, plays, shows, poems, songs, book titles). Section headings which refer to some other famous works in different areas may be very wellknown for an adult reader, but from the point of view of a child they may either go unnoticed in terms of the load of knowledge they carry in themselves or they may again call for an explanation, probably by an adult. Coupled with animal names as narrative elements, these headings imply that both the implied and the real readers of the book include more than one group: Sabahın Bir Sahibi Var (Morning has an owner; 34) ${ }^{11}$, Sakıncalı Paşa (The objectionable pasha; 54) ${ }^{12}$, Anadolu Ateşi (The Anatolian fire; 55) ${ }^{13}$, Ağaçlar Ayakta Ölür (Trees Die Standing Tall, 66) ${ }^{14}$, Fareler ve Insanlar (Of Mice and Men; 78) ${ }^{15}$, Eşklya Dünyaya Hükümdar Olmaz (Reign does not work on in highwayman world; 152) ${ }^{16}$, Doğu Cephesinde Yeni Bir Şey Var! (All quiet on the eastern front!; 157) ${ }^{17}$, Motoru Maviliklere Sürüyoruz (We drive our motor cars to blue horizons; 178) ${ }^{18}$, Bekle Bizi İstanbul (Wait for us Istanbul; 186) ${ }^{19}$, Savaş ve Barlş (War and Peace; 188) ${ }^{20}$, Silahlara Veda (A Farewell to Arms; 193), etc. ${ }^{21}$

\subsection{Omissions}

As "a political history based on documents pertaining to one of the most important periods of Turkey" (Velidedeoğlu 1998, 31), the source text contains many documents and names. Even in editions aiming at adult readers, the majority of the documents (such as correspondences, long discussions, maps) has been omitted with the thought that these sections would probably not appeal to people in general. Hence, it is no surprise that in children's editions, not only these documents but also names of people have been omitted to a great extent except for the ones who are still known figures in the Turkish history due the role they played in the past:

\footnotetext{
${ }^{11}$ A poem and song by Ruhi Su.

${ }^{12}$ The title is inspired by Uğur Mumcu's book Sakıncall Piyade (Objectionable infantry).

${ }^{13}$ The title of a dance show by Mustafa Erdoğan.

14 The title of Casona's play.

15 The title of Steinbeck's book.

16 The title of Sabahattin Ali's poem.

${ }^{17}$ The title inspired by Erich Maria Remarque's book All Quiet on the Western Front.

${ }^{18}$ A verse by Nazım Hikmet Ran.

19 The title of a poem by Vedat Türkali.

20 The title of Tolstoy's book.

${ }^{21}$ The title of Hemingway's book.
} 
Without any delay I went to İsmet Pasha's headquarter in Karacahisar. ${ }^{22}$ (135)

For this purpose, they stalled Fethi Bey, our minister of internal affairs we sent to England, for days. ${ }^{23}$ (176)

It is worth noticing though that the main points of important events such as Amasya Declaration or Erzurum and Sivas congresses have not been omitted; on the contrary, they have been given by summarizing and underlining their importance for the Turkish history, just like in a coursebook. The educative role of the narration is manifested once again:

At this congress [Erzurum Congress] we talked about national borders for the first time. ${ }^{24}(70)$

\subsection{Additions}

The educational role of Atatürk'ün Anlatımıyla Nutuk reveals itself mainly in additions. With extra sections that are not included in the source text, it must have been aimed to present a comprehensive picture of Atatürk's ideas and of the Turkish War of Independence. What is significant for the purpose of the present article though is that additions mainly comprise wellknown stories about Atatürk; this preference can be considered as contributing to the narratological feature of the text. Narrating already famous 'stories' can attract and maintain the attention of children; after all, children are eager to listen to a story they like again and again. ${ }^{25}$

The birthday of Atatürk, for example, although not mentioned in any part of the source text and not been officially confirmed up to the present, is used as a narratological element:

Therefore, I picked this important turning point in our history, namely May 19, as my birthday. ${ }^{26}(22)$

A similar example is a popular anecdote used as an introduction to a section found in the source text:

\footnotetext{
${ }^{22}$ Gecikmeksizin İsmet Paşa'nın Karacahisar'daki karargahına gittim.

23 Bu amaçla İngiltere'ye gönderdiğimiz içişleri Bakanımız Fethi Bey’i günlerce oyaladılar.

24 Bu kongrede [Erzurum Kongresi] ilk kez ulusal sinırlardan bahsettik.

25 It is of course possible to increase the number of examples but I preferred to choose the most self-explanatory ones for brevity's sake.

${ }^{26}$ Bu nedenle tarihimizdeki bu önemli dönüm noktasını yani 19 Mayıs’ı doğum günüm olarak belirledim.
} 
Our enemies used to call the Ottoman Empire "the sick man." In order to see whether the sick man died or not, a committee was sent to Anatolia by the American government. ${ }^{27}(89)$

Whereas Atatürk's voyage to Samsun is given in Nutuk in just a short paragraph, the way this paragraph is given in the translated text is probably the most prominent example underlining the narrative character of the book. For comparison, a different translation is provided first.

He [Rauf Bey] had heard from a confidential source that the ship I was going [on] would be followed and that it was very likely that she would be sunk in the Black Sea, if I could not be detained in İstanbul. This is what he came to tell me. I preferred to risk being drowned rather than being made prisoner in İstanbul, so I started off. (Atatürk $2008,24-25)^{28}$

As soon as we started off, we realized that Rauf Bey was right. An English warship began to follow our boat. It didn't get off our tail for a long time. Thinking the crew and the soldiers accompanying me, I pretended to be unaware of the situation. But I continuously kept an eye on the English ship behind us.

Hours passed.

... Our boat was swaying form one side to the other, from time to time she even became invisible on the sea. There was almost zero visibility. We were quite away from the shore.

What a fate that is! Was everything going to end right at the beginning?

... Fortunately, we managed to lose ourselves thanks to the stormy weather of the Black Sea. ${ }^{29}(17-19)$

These stories added to Atalay's edition owe their narrative character not only to their length and language, but also and equally importantly to their emphasis on expression of feelings and inner thoughts, which makes the tone of the book very different from the one in the source text.

\footnotetext{
${ }^{27}$ Düşmanlarımız Osmanlı Devleti’ne "hasta adam” adını vermişlerdi. Hasta adamın ölüp ölmediğini yerinde incelemek üzere Anadolu’ya Amerikan Hükümeti tarafından bir heyet gönderilmişti.

${ }^{28}$ [Rauf Bey] bineceğim vapurun izleneceğini, İstanbul'da iken tutuklamadıklarına göre, belki de Karadeniz'de batırılacağımı güvenilir kimselerden işitmiş, onu bildirdi. Ben İstanbul'da kalıp tutuklanmaktansa batıp boğulmayı yeğledim ve yola çıktım. (Velidedeoğlu 1998, 55)

${ }_{29}^{2}$ Yola koyulur koyulmaz anladık ki Rauf Bey haklıymış. Bir İngiliz savaş gemisi vapurumuzu izlemeye başladı. Uzun süre peşimizi bırakmadı. Mürettebata ve yanımdaki askerlere hiç renk vermedim. Bir gözüm sürekli arkamızdaki İngiliz gemisindeydi.

Saatler böylece geçti.

. . . Vapur bir o yana bir bu yana sallanıyor, bazen neredeyse suda görünmez hale geliyordu. Görüş mesafesi sıfıra yaklaşmıştı. Kıyıdan epey uzaklaşmıştık.

Feleğin işine bakın. Daha yolun başındayken her şey bitecek miydi?

.. . Talih ki Karadeniz'in firtınalı havası sayesinde izimizi kaybettirmeyi başardık.
} 


\subsection{Tone}

At this point, it is necessary to mention Schiavi's (1996) article. She refers to van Leuven-Zwart's (1990) term "translation's narrator" (quoted in 7) and the ambiguity it creates: "It [translation's narrator] can either be taken to mean the 'narrator contained in the translated text' or 'the narrator of the translation,' i.e. the entity by which the translation is told" (7).

The narrator 'in the translated text' evokes the idea that there is also a narrator in the source text, as a narrative element. However, since the source text in this case is not a narration, it would not be logical to talk about a narrator in this sense. Hence, it can be argued that the translator, adopting the narrative framework as his translation strategy, not only translated within the same language but also between the two genres and for this purpose he created, via his implied translator, a narrative element, namely a narrator 'for his translation' that will act both as the narrator 'of his translation' and 'of his translated text.' The reason that the tone used by this narrator in the translated text differs greatly from the tone of the source text can be linked to the transfer between the two genres:

Oh! What painful and mournful days they were $\ldots{ }^{30}(30)$

My ocean-hearted friends, I told you everything with its right and wrong. I had a talk with you, I had a heart-to-heart talk with you. ${ }^{31}(21)$

At some point, this heart-to-heart talk even receives a response from the narratee, another narrative element created by the implied translator in the process:

I want to ask you: "What would you do in this case?" Please tell me.

"Pasha, there is an enemy invasion. There is a tired army. There is a miserable people. There is hunger. There are so many problems. But there is no gun, no ammo. That must be the real despair.

$$
\text { ... You talked nicely and properly. I thought just like you. }{ }^{32}(38-40)
$$

The fictional setting of the narration envisionaged for this conversation to take place is akin to the real one in the source text; the narrator and the narratee are presumably in a meeting room, just like Atatürk and the party members:

\footnotetext{
${ }^{30} \mathrm{Ah}$ ahh ne ac1lı ve ne yaslı günlerdi ...

${ }^{31}$ Okyanus yürekli arkadaşlarım, hatasıyla, sevabıyla her şeyi size anlattım. Sizinle sohbet ettim, sizinle dertleştim.

${ }^{32}$ Size sormak istiyorum: "Ya siz ne yapardınız bu durumda?" Söyleyin lütfen.

"Paşam, düşman işgali var. Yorgun bir ordu var. Perişan bir halk var. Açlık var. Var da var. Ama silah, cephane yok. Gerçek çaresizlik bu olsa gerek.

. . . Çok güzel ve yerinde konuştunuz arkadaşlar. Ben de aynen sizin gibi düşündüm.
} 
Yeees ... I guess we are ready now. I see newcomers back there ... ${ }^{33}(10)$

They even take breaks during the session:

Yes, now we can take a lunch break.

If it is OK for everyone, let's meet here in an hour please . . . ${ }^{34}(87)$

Atatürk'ün Anlatımıyla Nutuk does not tell the source text 'as a story' in an indirect speech as many editions addressing children choose to do; instead it 'makes a story out of it.'

Hello my dear friends,

I am so happy to be with you and have the chance to have a talk with you. I am also very excited. Undoubtedly you know me. Still, I will be more than happy if I can get you to know me better!

What I am about to tell is completely my observations and the events I witnessed. Of course, I accept everything I did, right or wrong.

My conscience is clear. There is nothing I can't account for.

... I even prepared a work called "Nutuk" in which I talked about our national struggle.

... That said, this is the first time I find the opportunity to talk to you this long and directly. We can handle and discuss this process directly and sincerely. This way, I hope to summarize for you the events I talked about in my work, "Nutuk." 35 (5-6)

\section{Manipulation in Translation}

Manipulation in translation, introduced to the realm of translation studies by the Manipulation School, is explained by André Lefevere (1992) based on the concept of rewriting as translation itself being a rewriting and rewriting itself being a manipulation. Another representative of the same school, Theo Hermans (1985) notes that "all translation implies a degree of manipulation of the source text for a certain purpose" (11).

\footnotetext{
${ }^{33}$ Eveeet . . . Hazırız artık galiba. Yeni gelen arkadaşları görüyorum arkalarda . . .

${ }^{34}$ Evet şimdi yemek arası verebiliriz.

Herkes için uygunsa, tam bir saat sonra burada buluşalım lütfen . . .

${ }^{35}$ Merhaba sevgili dostlarım,

Sizinle beraber olduğum ve sohbet etme şansı bulduğum için çok ama çok mutluyum. Aynı zamanda büyük bir heyecan içindeyim. Kuşkusuz beni tanıyor ve biliyorsunuz. Yine de kendimi, sizlere daha iyi tanıtabilirsem ne mutlu bana!

Birazdan anlatacaklarım tamamen benim gözlemlerim ve şahit olduğum olaylardır. Elbette yaptıklarım hatasıyla ve sevabiyla bana aittir.

Vicdanım rahat. Hesabını veremeyeceğim bir şey yok.

. . . Hatta ulusal mücadelemizi konu edindiğim "Nutuk" adlı bir eser bile hazırlamıştım.

... Bununla birlikte ilk kez sizinle bu kadar uzun ve doğrudan sohbet etme imkanı buluyorum. Dolaysız ve samimi bir şekilde bu süreci beraberce ele abilir ve tartışabiliriz. Böylelikle "Nutuk" adlı eserimde anlattı̆̆ım olayları sizin için özetlemiş olmayı umuyorum.
} 
O'Sullivan (2003), in her article, approaches the subject from the perspective of change in relation to the "agent of the translation, the translator" and the level of his/her presence in the target text; in her communicative model of translation, the implied translator is the one who determines which important changes will take place. O'Sullivan emphasizes that the audibility of the implied translator is most significant especially in children's literature due to the "asymmetrical nature of the communication" between the adult creator of the text to be read and the child reader (198). The field of narratology meets the field of translation studies in O'Sullivan's model and the subject of study in the present article proves to be an example of manipulation in translation where narratology used as the translation strategy has created its implied translator who claims to be 'the author' of the target text and who claims to have ‘children' as his target reader.

\section{Concluding Remarks}

Two areas can be considered as manipulative in this regard. The first one is the real reader. Although the cover of the book clearly defines its real target reader by saying Çocuklar için (for children) and although the translation is full of narrative elements that would appeal to children, the text calls for the presence of an adult and his/her explanations in many parts in order for its content to be fully understood. It is a common fact that children have adults read them children's books probably either because they are not literate yet or because they just like it or still because they want an explanation from them in case a question about the book pops up in their mind. What is uncommon in this specific case, however, is the nature of some information contained in the text. Even if we put aside, for example, the section headings with implications mentioned before, the terms of distopya (dystopia; 12), ya basta ${ }^{36}$ (enough is enough; 42) or magnum opus $^{37}$ (masterpiece; 201), which even a well-educated adult may need to look up in a dictionary, would be enough to raise questions about the "real" reader of the book. The discrepancy between the target reader specified on the cover and the linguistic, stylistic and informative load 'under the cover' can be argued to be manipulative in the framework of translation studies.

\footnotetext{
${ }^{36}$ A Spanish word.

${ }^{37}$ A Latin word.
} 
The second one is the real author. Atalay seems to argue to have written a new book inspired by Atatürk's Nutuk and therefore has been called the author of this new book on the copyright page, whereas on the cover we see Nutuk as the title and Atatürk's signature.

Although nowhere in the book Nutuk is given as the 'source text,' the cover itself proves that Atalay's work is 'based on' it. Also, according to both Chatman's and O'Sullivan's diagrams, the source text is Nutuk and the real author is Mustafa Kemal Atatürk. Whether Atalay's work is based on the 'original' Nutuk or on its later editions does not change the fact that there is a source text.

Atatürk'ün Anlattmıyla Nutuk is a flesh and blood example of O'Sullivan's model where the translator, by using the narratological framework as his translation strategy, via his implied translator, not only translates between genres by creating a narration for children out of a historical book written mainly for adults, but also, in his intralingual translation benefits from all narrative elements, takes advantage of his position as "the agent of 'change"' (O'Sullivan 2003, 197), and becomes as visible and audible as possible.

Atalay's work can be said to be simply inconsistent in terms of the identities, both of the author and the reader. Nevertheless, this inconsistency, when considered from the perspective of translation studies, leads to some questions.

Regardless of how loud or low the translator's voice is, is it not manipulative to present the translator as the author on the copyright page while the cover carries the name of the source text and the signature of its author? Or to define the target reader on the cover and not to speak in a language or not to talk about a content that the target reader would expect and be able to understand?

Or, apart from evaluating it as manipulative, can we consider Atalay's work as a 'modern, intralingual example' of "tercüme yoluyla telif" (translation-based 'telif'), a concept discussed elaborately by Saliha Paker (2014, 36-71) in her article “Terceme, Te'lîf ve Özgünlük Meselesi." This intralingual translation-based 'telif' may be the subject of another study. 
transLogos 2019 Vol 2 Issue 1

Kalem Bakkal, Asl1, pp. 85-101

From the 'Real' Author to the 'Real' Reader:

Manipulation in Translation trans Dogos

A Translation Studies Journal

(c) Diye Global Communications diye.com.tr|diye@diye.com.tr

\section{Appendices}

Fig. 3. The Book's Cover (top), Inner Cover (bottom left) and Copyright Page (bottom right)
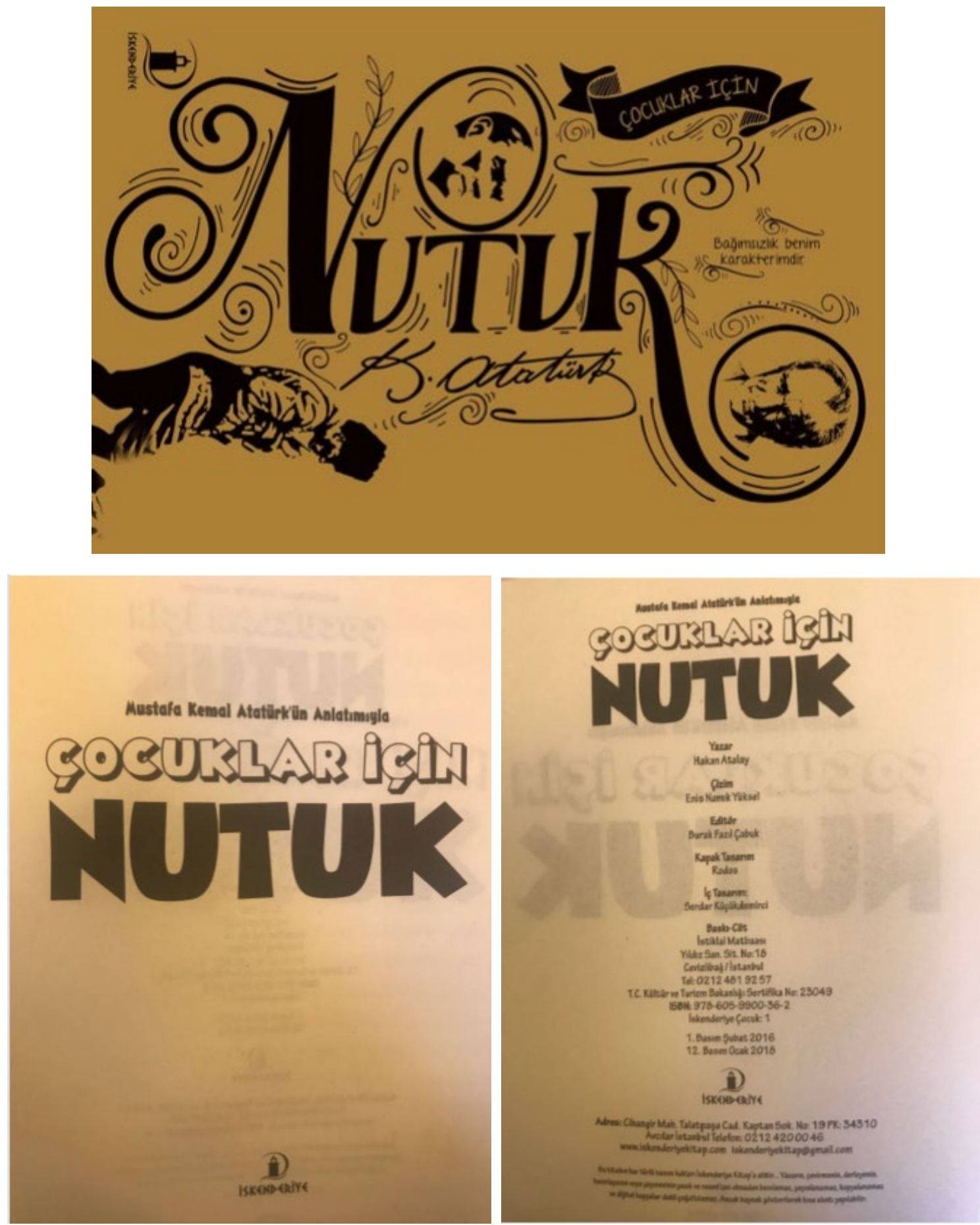


\section{References}

Atalay, Hakan, ed. 2018. Çocuklar için Nutuk [The great speech for children]. By Mustafa Kemal Atatürk. Istanbul: İskenderiye.

Atatürk, Mustafa Kemal. 1927. Nutuk [The great speech]. Ankara: Türk Teyyare Cemiyeti. 1934. Nutuk [The great speech]. Istanbul: Devlet Matbaas1.

- 2008. The Great Speech. Ankara: Atatürk Research Center.

Balpınar, Özgür, ed. 2019. Çocuklar için Nutuk. [The great speech for children]. By Mustafa Kemal Atatürk. Istanbul: Lades Kitap.

Berk Albachten, Özlem. 2013. “Intralingual Translation as 'Modernization' of the Language: the Turkish Case.” Perspectives 21 (2): 257-271. doi: 10.1080/0907676X.2012.702395.

Berktay, Ali, ed. 2016. Gençler için Fotoğraflarla Nutuk [The great speech with photographs for the youth]. By Mustafa Kemal Atatürk. Istanbul: Türkiye İş Bankası Kültür Yayınları.

Bilici, Ali Rüştü, ed. 2017. Mustafa Kemal Atatürk'ten Gençliğe: Çocuklar için Nutuk [from Mustafa Kemal Atatürk to the youth: the great speech for children]. By Mustafa Kemal Atatürk. Istanbul: Elhamra.

Chatman, Seymour. 1978. Story and Discourse: Narrative Structure in Fiction and Film. Ithaca: Cornell University Press.

—. 1990. Coming to Terms: The Rhetoric of Narrative in Fiction and Film. Ithaca: Cornell University Press.

Demirel, Yücel, ed. 2018. Günümüz Türkçesiyle Nutuk [The great speech in today’s Turkish]. By Mustafa Kemal Atatürk. Istanbul: Yapı Kredi.

Doğan, Erdal, ed. 2017. Nutuk: Illkögrretim Okulları için [The great speech: for the elementary school students]. By Mustafa Kemal Atatürk. Istanbul: Say.

Hermans, Theo, ed. 1985. The Manipulation of Literature: Studies in Literary Translation. London: Croom Helm.

Jakobson, Roman. (1959) 2000. "On Linguistic Aspects of Translation.” In The Translation Studies Reader, edited by Lawrence Venuti, 113-8. London: Routledge.

Kalecikli, Kenan, ed. 2017. Ilköğretim Öğrencileri için Nutuk (Söylev) [The great speech (the great discourse) for the elementary school students]. By Mustafa Kemal Atatürk. Ankara: Delta Kültür. 
transLogos 2019 Vol 2 Issue 1

Kalem Bakkal, Asl1, pp. 85-101

From the 'Real' Author to the 'Real' Reader:

Manipulation in Translation trans Dogos

A Translation Studies Journa

(C) Diye Global Communications diye.com.tr|diye@diye.com.tr

Korhan, Kaan Kemal, ed. 2018. Cumhuriyetimizin Emanetçisi Olan Çocuklarımız için Nutuk [The great speech for children who are the guardians of our republic]. By Mustafa Kemal Atatürk. Ankara: Kripto Kitaplar.

Lefevere, André. 1992. Translation, Rewriting, and the Manipulation of Literary Fame. London: Routledge.

O'Sullivan, Emer. 2003. "Narratology Meets Translation Studies; or, The Voice of the Translator in Children's Literature." Meta 48 (1-2): 197-207. doi: 10.7202/006967ar.

Paker, Saliha. 2014. "Terceme, Te’lîf ve Özgünlük Meselesi.” In Eski Türk Edebiyatı Çalışmaları - IX Metnin Hâlleri: Osmanlı'da Telif, Tercüme ve Şerh, edited by Hatice Aynur, Müjgân Çakır, Hanife Koncu, Selim S. Kuru, and Ali Emre Özyıldırım, 36-71. İstanbul: Klasik.

Schiavi, Giuliana. 1996. "There is Always a Teller in a Tale." Target 8 (1): 1-21. doi: 10.1075/target.8.1.02sch.

Velidedeoğlu, Hıfzı Veldet, ed. 1998. Söylev [The great discourse]. 2 vols. Istanbul: Çağdaş. 